\title{
ON $\lambda$-PSEUDO-STARLIKE FUNCTIONS
}

\author{
K. O. BABALOLA
}

Abstract. In this paper, we isolate some new, interesting classes of $\lambda$-pseudo-starlike univalent functions in the open unit disk $E=\{z \in \mathbb{C}:|z|<1\}$. Some characterizations of them are obtained and examples given.

Mathematics subject classification (2010): 30C45.

Keywords and phrases: Bazilevič functions, $\lambda$-pseudo-starlike, analytic and univalent functions.

\section{REFERENCES}

[1] K. O. Babalola And T. O. Opoola, On the Coefficients of a Certain Class of Analytic Functions, Advances in Inequalities for Series. Nova Science Publishers Inc., New York, (2008), 1-13.

[2] B. A. FRASIN AND J. M. JAHANGIRI, A new and comprehensive class of analytic functions, Analele Universitatii din Oradea, Tom XV (2008), 61-64.

[3] A. E. Livingston, The coefficients of multivalent close-to-convex functions, Proc. Amer. Math. Soc. 21 (1969), 545-552.

[4] S. S. Miller And P. T. Mocanu, Differential Subordinations: Theory and Applications, Marcel Dekker, New York, Basel 2000.

[5] R. SingH On Bazilevič Functions, Proc. Amer. Math. Soc. 38 (1973), 261-271. 